\title{
European Slave Trading, Abolitionism, and 'New Systems of Slavery' in the Indian Ocean
}

\author{
Richard B. Allen, Framingham State University ${ }^{1}$
}

In April 1827, the captain of the Dutch brig the Swift retained Mahomet, a native of Surabaya on the north coast of Java, to recruit workers from the countryside around the city. Mahomet, who already knew the brig's captain, soon secured the services of a number of men and women by giving them twenty rupees as two months' advance wages and telling them that they would be going to work in Singapore or Batavia. After the ship left Surabaya, however, these workers learned that they were actually bound for the French colony of Ile de Bourbon (Réunion) in the southwestern Indian Ocean, a discovery that led them to demand they be returned to Java. Not unsurprisingly, their demands fell on deaf ears and the four men, four women, and one child who survived the Swift's subsequent wreck at Rodrigues, the easternmost of the Mascarene Islands and a dependency of the British colony of Mauritius 350 miles away, ended up in Mauritius where their ultimate fate remains unknown. ${ }^{2}$

The story of the Swift's passengers highlights some of the problems inherent in assessing the status of migrant labourers in the Indian Ocean world during the early and mid-nineteenth century. Prominent among these are the difficulties of distinguishing

\footnotetext{
${ }^{1}$ This is an expanded and revised version of an article in Slavery and the Slave Trades in the Indian Ocean World: Global Connections and Disconnections, (eds) R. Harms, B. K. Freamon \& D. Blight, Yale University Press, New Haven, in preparation.

${ }^{2}$ CO 415/9/A.221 - Documents relating to the Dutch Brig Swift which was wrecked at Rodrigues in August 1827 with Malays on board. Twelve 'Malay' men and two women on board the ship drowned when it was wrecked.

PORTAL Journal of Multidisciplinary International Studies, vol. 9, no. 1, January 2012. Indian Ocean Traffic Special Issue, guest edited by Lola Sharon Davidson and Stephen Muecke. ISSN: 1449-2490; http://epress.lib.uts.edu.au/ojs/index.php/portal PORTAL is published under the auspices of UTSePress, Sydney, Australia.
} 
'free' from 'unfree' labour during an era that witnessed the demise of the legal British and French slave trades, the abolition of slavery in the British and French empires, and the emergence of a purported 'new system of slavery' that led to the migration of millions of indentured African, Asian, and other non-European labourers throughout the colonial plantation world and beyond during the nineteenth and early twentieth centuries. The ambiguities surrounding the status of the Javanese men and women on the Swift are an early illustrative case in point. On the one hand, these individuals apparently knew what they were doing when they agreed to work as wage labourers in Singapore or Batavia and did so of their own accord. On the other hand, the fact that they were deliberately deceived about their real destination and their demands to be returned to Java were ignored are consistent with the deceptive and coercive practices often used to secure the services of contract labourers in the early nineteenth-century colonial world. That the Swift sailed at a time when French ships transported illegal cargoes of slaves from the Indonesian archipelago to Réunion, ${ }^{3}$ when British-flagged vessels reportedly could be found occasionally carrying slaves near the Seychelles, ${ }^{4}$ and when Dutch and British vessels frequented Diego Garcia with 'Malays' of uncertain legal status on board ${ }^{5}$ underscores the difficulties of assessing the impact that European, and especially British, abolitionism had on forced migrant labour systems in the Indian Ocean basin. So does the fact that Mahomet's statement about his activities was among the documents submitted to the Commission of Eastern Enquiry during its investigation into the illegal slave trade to Mauritius which flourished from 1811 to circa 1827 (Allen 2001a).

The origins of the modern system of migrant contract labour date to the mid- and late 1820s when the first, ultimately unsuccessful attempts were made to employ free Chinese and Indian workers on Mauritius and Réunion (Ly-Tio-Fane Pineo 1984: 14 17; Carter \& Ng 1997: 4-5; Weber 2002: 309-10). Mauritius has long been acknowledged as the crucial test case for the use of free contractual or indentured labour in the colonial plantation world following British slave emancipation in 1834

\footnotetext{
${ }^{3}$ CO 415/1, pp. 15, 17, W.M.G. Colebrooke and W. Blair to Earl Bathurst, 25 Oct. 1826; CO 415/7/A.164, Memorandum from Captain Ackland for Mr. Finniss [written after 13 Sept. 1826]. On the illegal slave trade to Réunion, see Gerbeau (1979a, 2002), Carter and Gerbeau (1988), Daget (1996) and Finch (2005).

${ }^{4}$ IOR: F/4/1331/52588, p. 70, Statement of the Master of the Brig Hebe/as related to by the Captain of the Pecheur Schooner at Mahé, 20 Oct. 1830.

${ }^{5}$ CO 415/1, p. 27, W.M.G. Colebrooke and W. Blair to Earl Bathurst, 21 Nov. 1826.
} 
(Cumpston 1953: 85), and the arrival of seventy-five privately recruited Indian workers on the island on 2 November 1834 is widely regarded as marking the advent of this modern migrant labour system. The success of the Mauritian experiment with indentured labour led to more than two million Africans, Chinese, Indians, Japanese, Javanese, and Melanesians leaving their homes to work on plantations and in other enterprises in the Caribbean (British Guiana, Cuba, Guadeloupe, Jamaica, Martinique, Surinam, Tobago, Trinidad), eastern and southern Africa (Kenya, Natal, Transvaal, Uganda), southern and Southeast Asia (Burma, Ceylon, Malaya), the southwestern Indian Ocean (Mayotte, Nosy Bé, Réunion), Australasia (New Caledonia, Queensland), the central and southern Pacific (Fiji, Hawai'i, Tahiti), and Central and South America (Mexico, Peru) between the mid-1830s and the early 1920s (Northrup 1995: 156-60). Indentured labour also became an important component of regional political economies in India, especially in Assam and adjacent areas (Behal \& Mohapatra 1992; Das Gupta 1992, 2005).

Nineteenth-century British abolitionists first argued that the deception and coercion used to recruit indentured labourers and the exploitation and oppression to which they were subject during their indentures made these men and women little more than victims of a 'new system of slavery.' The experience of the first indentured Indian immigrants to Mauritius gave substance to these suspicions, and the public outcry in Britain and India about their mistreatment led to the suspension of the so-called 'coolie' trade to the island in $1838 .{ }^{6}$ When Indian emigration to Mauritius resumed late in 1842 , it did so under governmental supervision to limit further abuse of these workers. Hugh Tinker echoed these abolitionist sentiments in his classic study on the exportation of Indian labour after British slave emancipation (Tinker 1974), a work that continues to influence studies of the indentured experience. The Tinkerian paradigm has not been without its critics, however; several scholars have argued that characterizing indentured labour systems in these terms is at least something of a misnomer (Brereton 1994; Carter 1995: 1-6; Northrup 1995: 154).

At the heart of this historiographical tradition is a preoccupation with assessing whether indentured labourers were really 'free' or 'unfree' and ascertaining the extent to which

\footnotetext{
${ }^{6}$ See the reports of the commissions of inquiry based in Mauritius (PP 1840 XXXVII [58], 18-35, 4568, and PP 1840 XXXVII [331], 12-94, 107-83), and in Calcutta (PP 1841 XVI [45], 4-12) on early indentured immigrant living and working conditions.
} 
they exercised control over their own lives and destinies (Baak 1999; Allen 2002). The nature and dynamics of labour control figure prominently in these assessments that also tend to focus on the legal and quasi-legal dimensions of workers' lives. While this approach has shed substantial light on various aspects of the indentured experience, it has also limited our understanding of these migrant labour systems and their role in shaping the modern capitalist global economy. One consequence is widespread acceptance of the notion that indentured workers were little more than the hapless and helpless victims of unscrupulous labour recruiters, plantation owners, and colonial officials. Another consequence is a frequent failure to examine other important aspects of the indentured experience such as the place and activities of women in these systems, the role of gender in shaping local socio-economic relations, and the extent to which indentured workers exercised agency on their own behalf. ${ }^{7}$ A review of studies of these labourers in Australasia (Shlomowitz 1982; Graves 1993; Shineberg 1999), the Caribbean (Adamson 1972; Mandle 1973; Schuler 1980; Look Lai 1993; Laurence 1994; Hoefte 1998; Kale 1998), South Africa (Tayal 1977; Richardson 1984), the South Pacific (Gillion 1962; Mayer 1963; Lal 1983), and Southeast Asia (Jain 1970, 1984; Breman 1989; Ramasamy 1992) highlights an attendant failure to view the indentured experience in individual colonies in larger global and comparative contexts (Allen 2001b). Lastly, few attempts have been made to explore possible structural connections between pre- and post-emancipation labour systems in the colonial world. Studies of British slave plantation colonies usually come to an end with the abolition of slavery in 1834 (or occasionally with the collapse of the 'apprenticeship' system in 1838), while those that deal with post-emancipation labour systems in these colonies pay little or no attention to the slave regimes that preceded them. Discussions of the conceptual and interpretative issues surrounding indentured labour (Newbury 1975; Marks \& Richardson 1984; Van Den Boogaart \& Emmer 1986; Munro 1993, 1995; Shepherd 2002) also reflect this propensity to draw a sharp dividing line between the pre- and post-emancipation eras in the colonial plantation world.

Recent scholarship on migrant labour in the Indian Ocean underscores the need to explore the connections between pre- and post-emancipation labour systems more fully. Mauritian archival sources, for example, confirm the existence of the kind of structural links between slave systems in India and the exportation of Indian indentured labour

\footnotetext{
${ }^{7}$ Exceptions include Jolly (1987), Carter (1994), Mohammed (1995), Shepherd (1995) and Allen (1999).
} 
first proposed more than forty years ago by Benedicte Hjejle. In her seminal article on slavery and agricultural bondage in southern India, Hjejle argued that the recruitment of some indentured Indians cannot be understood without reference to indigenous systems of slavery, and that a significant number of the migrant workers who reached Ceylon between 1843 and 1873 came from the ranks of South India's praedial slave population (Hjejle 1967: 106). The registers that recorded the arrival of indentured Indians in Mauritius confirm that the labourers who arrived on the island from southern India during the late 1830s included individuals of 'slave' caste status. ${ }^{8}$ Unfortunately, it is unclear how many such individuals reached the island during or after the mid-1830s or may have been among the indentured immigrants who reached other plantation colonies during the nineteenth century. Comparable structural links are a hallmark of the engagé system which entailed the recruitment of ostensibly liberated slaves and free contractual labourers along the East African coast and in Madagascar to work on Mayotte in the Comoros, Nosy-Bé off Madagascar's northwest coast, and Réunion following France’s abolition of slavery in 1848 (Renault 1976; Ly-Tio-Fane Pineo 1979; Gerbeau 1986; Fuma 2000; Monnier 2006). This system is widely regarded as little more than the old slave trade in new garb.

We currently know little about the details of indentured labour recruitment in India before 1842 when governmental regulation of this system began. However, information about servile agricultural labour in early nineteenth-century southern India, the exportation of slaves from the subcontinent during the late eighteenth and early nineteenth centuries, and the indigenous migrant labour systems that supplied indentured Indian workers to Mauritius before 1838 provide additional, if indirect, evidence of structural links between the slave and indentured labour trades in the Indian Ocean. An official inquiry during 1819 into slavery in the Madras Presidency reported that masters in some areas in southern India had a relatively free hand in disposing of their servile dependents if they chose to do so. Such was the case in Trichinopoly where the district's collector, C. M. Lushington, reported that while 'Pullers' (Pulayas) were usually sold with the land they worked, they were also frequently sold independently of the land in question, ${ }^{9}$ a development that raises questions about exactly how Vyavry,

\footnotetext{
${ }^{8}$ MGI: PE 1. The individuals in question were members of the Palin and Pulaya castes.

${ }^{9}$ IOR: F/4/919/25850, 134, C.M. Lushington to A.D. Campbell, 1 July 1819.
} 
aged twenty-eight and a 'Puller' by caste, reached Mauritius in $1838 .{ }^{10}$ Lushington also noted the 'indiscriminate' sale of men, women, and children in Malabar, an observation seconded by that district's collector who reported that slaves were frequently transferred from one owner to another by sale, mortgage or hire. ${ }^{11}$ These regions were well known to European slavers who operated along the Indian coast during the eighteenth century. The movement of slaves from Malabar to the French comptoir at Mahé and the Dutch factory at Cochin, for instance, became a subject of considerable concern to British authorities immediately following their acquisition of the province in 1792 (Duncan et al. 179?, vol. 1: 164-65, \& vol. 2: 35-36). Official consternation about the Malabar slave trade resurfaced no later than 1812 when British authorities considered how they might best bring an end to 'the nefarious traffic in Slaves which has prevailed on the Malabar Coast.' 12

The large number of slaves exported by Europeans from India during the eighteenth century likewise point to this trade laying the foundations, if not establishing some of the institutional structures, on which the indentured labour trades subsequently rested. Perhaps as many as 24,000 Indian slaves were exported to the Mascarenes from 1670 to 1810, 75 percent of whom were dispatched to these islands between 1770 and 1793 when British seizure of France's Indian possessions following the outbreak of war in Europe effectively ended the large-scale exportation of Indian slaves to the southwestern Indian Ocean (Allen 2004, 2005). Areas in southern India such as Malabar, Tanjore, and Tinnevelly, nevertheless continued to function as slave trading centres that attracted the attention of British officials during the 1810s, 1820s, and early 1830s. ${ }^{13}$ This continuing concern about slave exports from the Coromandel and Malabar coasts, and the funnelling of kidnapped and enslaved children from British territories to the French comptoir at Mahé in particular, becomes more comprehensible in light of the fact that the mid- and late-1820s witnessed French attempts to recruit indentured Indians to work on Réunion, undertakings in which the former slave trading enclaves of

\footnotetext{
${ }^{10}$ MGI: PE 1, No. 2415.

${ }^{11}$ IOR: F/4/919/25850, p. 174, J. Vaughan to Board of Revenue, 20 July 1819. On slavery in southern India, see Kumar (1965, esp. 34-48), Kurup (1973), Joseph (1987) and Udaya (2003).

${ }^{12}$ IOR: P/322/68, p. 2850, W ${ }^{\mathrm{m}}$ Thackeray to Judge and Magistrate Zillah, North Malabar, 29 May 1812.

${ }^{13}$ IOR: F/4/566/13970, Reports of Sir R. Dick \& ${ }^{\mathrm{a}}$ relative to the practice stated to have been prevalent of Inveighling away and Selling Slaves within the Division of Dacca [1813-16]; F/4/1128/30151,

Contraband trade carried on through Mahé [1819-20]; F/4/1034/28499, Slavery, Kidnapping and Sale of children in Tanjore and Tinnevelly [1825]; F/4/1414/55774, Relative to the Kidnapping of Children from the Company's Territory for Sale as Slaves [1830-33].
} 
Pondichéry, Karikal, and Yanam figured prominently (Northrup 1995: 60; Weber 2002: 309-10).

What little we currently know about indentured labour recruitment in India before 1838 likewise points to structural connections between the slave and indentured labour trades. Marina Carter notes that the labour exporters who supplied Mauritius with indentured Indians before 1838 tapped into indigenous migrant labour systems to do so, and that approximately one-third of the 7,000 Indians who arrived in Mauritius during 18371838 were dhangars or tribal hill people from southern Bihar (Carter 1995: 204). Hill tribesmen figured prominently among those who were enslaved in various parts of the subcontinent. An 1811 report about the trafficking of Nepalese into British territories in northern India, ${ }^{14}$ and an 1816 report on the movement of enslaved children from Assamese tribal areas to Bengal, ${ }^{15}$ an important source of slaves and then indentured labourers for the Mascarenes, suggests that the presence of individuals from the Himalayan and/or Assamese foothills among these early indentured recruits cannot be discounted pending further research. The need for such research is underscored by the request made in 1825 by the governor-general's agent on the northeastern frontier that Assamese who owed state service but could not fulfil their obligations because of the partial famine that had swept the region be allowed to sell themselves into slavery. ${ }^{16}$ Although the government in Calcutta promptly relinquished all of its claims to such service, British officials acknowledged that some Assamese had nevertheless 'contracted an obligation to serve private individuals for their lives during the pressure of the late famine.' 17

The depth and extent of the ties between the slave and indentured labour trades is also suggested by the scale of European slave trading in the Indian Ocean basin, especially during the late eighteenth and early nineteenth centuries (Allen 2008). Europeans purchased and transported enslaved Africans from Mozambique and the Swahili Coast to India, the Indonesian archipelago, and the Mascarenes; Indians to Ceylon, Indonesia, the Mascarenes, and South Africa; Malagasies to India, Java, the Mascarenes, and

\footnotetext{
${ }^{14}$ IOR: F/4/369/9221, Relative to the Measures adopted for the prevention of the Trade in Children carried on between the Upper Provinces and the Territories of Napaul.

${ }^{15}$ IOR: F/4/566/13970, pp. 32-33, J.W. Sage to Shearman Bird et al., 12 Feb. 1816.

${ }^{16}$ IOR: F/4/1115/29887, pp. 3-4, D. Scott to Mr. Chief Secretary Swinson, 4 Mar. 1825.

${ }^{17}$ IOR: F/4/1115/29887, pp. 7-8, Mr. Acting Secretary Stirling to D. Scott, 3 Apr. 1825.
} 
Sumatra; and men, women, and children from Bali, Java, Makassar, Nias, Sumatra, and Timor to Ceylon, India, the Mascarenes, and South Africa. A review of published scholarship indicates that British, Dutch, French, and Portuguese traders purchased and transported at least 431,000 to 547,000 slaves to their Indian Ocean establishments between 1500 and 1850. The data at our disposal also point to a four- or possibly fivefold increase in the volume of this traffic between the seventeenth and eighteenth centuries, with much of this growth occurring after 1770, and indicate that Europeans continued to trade large numbers of slaves within the Indian Ocean basin well into the nineteenth century (Allen 2010).

The scope and scale of this activity becomes even more impressive when note is taken of European exports from the Indian Ocean to the Americas. Slaves from South Asia occasionally reached the New World. In 1778, for example, La Cibèle landed 258 men, forty-nine women, fifty-seven boys, and twenty-two girls from 'the coasts of India' at Saint Domingue (Mettas 1978: 613-14). As the updated Trans-Atlantic Slave Voyage Database attests, the number of slave exports from Mozambique and Madagascar to the Americas increased steadily, rising from 11,825 during the seventeenth century to 58,180 during the eighteenth century and then soaring to 324,871 between 1801 and 1860 (Trans-Atlantic Slave Trade Database 2009). ${ }^{18}$ These figures are indicative of the minimum number of such exports; in comments on this revised database, David Eltis and David Richardson (2008: 46-47) estimate that Southeast Africa exported 31,715 slaves to the Americas during the seventeenth century, 70,931 during the eighteenth century, and 440,022 during the nineteenth century. What is clear from these data is that 76-85 per cent of all Mozambican and Malagasy slaves shipped across the Atlantic were exported between 1781 and 1840. These figures, when added to those on slave trafficking within the Indian Ocean noted earlier, suggest that Europeans were involved in the purchase and transportation of at least 826,000 and perhaps as many as $1,089,700$ slaves within and beyond the confines of the Mare Indicum between 1500 and 1850 . Future research will undoubtedly lead to further refinement of these figures.

When viewed in its totality, this activity points to the existence of increasingly integrated networks of free and unfree or forced migrant labour within and beyond the confines of the Indian Ocean world by the late eighteenth century. The

\footnotetext{
${ }^{18}$ See Trans-Atlantic Slave Trade Database (2009).
} 
interconnectedness of these networks can be illustrated in other ways. Recent scholarship reveals that significant numbers of Indian and Southeast Asian convicts were transported across the Mare Indicum to satisfy the relentless demand for labour in European factories, administrative centres, and colonies. Dutch authorities first shipped convicts from Batavia and Ceylon to the Cape of Good Hope no later than 1688, and a small but steady flow of these convicts continued to reach the Cape during the eighteenth century (Armstrong 1999). ${ }^{19}$ British authorities, already versed in shipping approximately 50,000 convicts to their American colonies between 1718 and 1775 (Grubb 2000; Forster 2002), began transporting Indian convicts to British possessions elsewhere in the Indian Ocean basin during the late 1780s. Indian prisoners were first sent to the East India Company’s factory at Bencoolen (Benkulen, Bengkulu) in Sumatra in 1787, the same year that witnessed the departure from Britain of the first of the more than 160,000 convicts who reached Australia between 1788 and 1868. While the exact number of Indian prisoners subjected to transportation remains unknown, it is clear that tens of thousands suffered this fate. A minimum of 2,000 and perhaps as many as 4,000 to 6,000 were sent to Bencoolen between 1787 and 1825 while at least 15,000 to 20,000 were dispatched to the Straits Settlements (Malacca, Penang, Singapore) between 1790 and 1860. Slightly more than 1,500 Indian convicts arrived in Mauritius between 1815 and 1837, while some 5,000-7,000 were shipped to Burma from 1828 to 1862. The Andaman Islands, the site of an early, unsuccessful attempt (1793-96) to establish a penal colony in the Bay of Bengal, became a fully fledged penal colony following the Indian Mutiny of 1857-58 that ultimately housed some 50,000 prisoners before Japanese occupation of the islands during World War II ended the transportation of Indian convicts. ${ }^{20}$ British authorities also shipped 1,000 to 1,500 or more convicts from Ceylon (Sri Lanka) to Mauritius and the Straits Settlements during the midnineteenth century. Overall, British authorities dispatched at least 74,800 and perhaps as many as 90,000 South Asian convicts overseas between 1787 and 1943 (Yang 2003: 180; Anderson 2007: 188; Rediker, Pybus \& Christopher 2007: 9).

Events at Bencoolen also provide a vantage point from which to begin to consider the ways in which attempts to abolish slave trading, if not the institution of slavery itself, in

\footnotetext{
${ }^{19}$ My thanks to James Armstrong for permission to cite his paper. On forced migration in the Dutch East India Company's empire, see Ward (2009).

${ }^{20}$ On the convict experience in Mauritius and the Andamans, see Anderson (2000) and Sen (2000), respectively.
} 
parts of the Indian Ocean may have influenced the development of abolitionism in Britain and the ultimate recourse to indentured labour. The first shipment of Indian convicts to Bencoolen in 1787 coincided with the formulation of an ultimately abortive plan to emancipate the factory's slaves and engage them as wage labourers. ${ }^{21}$ This proposal was not an isolated or unique event. Thirteen years earlier, Governor-General Warren Hastings and his council had issued regulations to control slave trading in Bengal on the grounds that 'the practice of stealing Children from their Parents and selling them for Slaves has long prevailed in this Country, and has greatly increased since the Establishment of the English Government in it.' Hastings continued that this 'savage commerce' was so extensive that there appeared to be no effective way of 'Remedying this calamitous Evil' but to abolish 'the Right of Slavery altogether, excepting such Cases to which the Authority of Government cannot reach. ${ }^{22}$ Aside from these public pronouncements, the archival record is frustratingly silent about the motive behind these regulations, which also seem to have fallen quickly into disuse (Chattopadhyay 1977: 81).

Slavery and slave trading became a subject of official interest again no later than March 1785 when Matthew Day informed William Cowper that 'many hundreds' of children had been sold into slavery because of the famine then ravaging the countryside surrounding Dacca (Dhaka) and were being shipped to 'the Foreign Settlements [near Calcutta] from whence ... they are embarked in Vessels to different Parts., ${ }^{23}$ Day's report prompted Cowper to write to Governor-General John Macpherson requesting his 'speedy Interference to stop the pernicious Trade ... which is also as inhuman as it is illegal. ${ }^{24}$ This consternation continued after Lord Cornwallis became governor-general in 1786, and culminated in his proclamation of 22 July 1789 banning slave exports from the Bengal Presidency. ${ }^{25}$ The Madras Presidency followed his lead on 8 March $1790 .{ }^{26}$ The early 1790s found British authorities taking various steps to prevent children in particular from being sold into slavery and to impede the exportation of slaves from their Indian territories (Allen 2006: 2009).

\footnotetext{
${ }^{21}$ IOR: F/4/279/6417, p. 5, Extract of Separate Letter to Bengal Relative to Bencoolen, dated 31 July 1787.

${ }^{22}$ IOR: P/49/46, pp. 1484-85, Regulations issued 17 May 1774.

${ }^{23}$ IOR: P/50/60, M. Day to William Cowper, 2 Mar. 1785, following L.R. No. 311, W ${ }^{\mathrm{m}}$ Cowper to John Macpherson, 14 Mar. 1785, in Fort William proceedings of 9 Sept. 1785.

${ }^{24}$ IOR: P/50/60, W ${ }^{\mathrm{m}}$ Cowper to John Macpherson, 14 March 1785 - L.R. No. 311.

${ }^{25}$ IOR: P/3/46, pp. 488-93. See also Calcutta Gazette, Extraordinary, 27 July 1789.

${ }^{26}$ IOR: P/241/17, pp. 644, 682.
} 
Cornwallis's proclamation, which long preceded the 1807 parliamentary abolition of the British slave trade, is significant in the annals of abolitionism because it appears to have been part of a more comprehensive attack on the institution of slavery itself in India. Less than two weeks after issuing his proclamation, Cornwallis informed the East India Company’s Court of Directors in London that he was considering a plan to abolish slavery throughout the company's Indian territories in a way that would neither injure private interests nor antagonize the indigenous population. A simultaneous proposal to alleviate slaves' misery before they were freed suggests that he envisioned a program of gradual emancipation. ${ }^{27}$

Unfortunately, no copy of Cornwallis's plan survives in the archival record. ${ }^{28}$ The origins and depth of his abolitionist sentiments and the motive(s) behind the 1789 ban on slave exports from Bengal and his plan to abolish slavery in India likewise remain hidden from our view. His personal papers (Ross 1859) are silent about these matters, and contemporaries offer little insight into his possible motives other than to observe that he wanted to ensure the security, prosperity, and happiness of India's inhabitants. ${ }^{29}$ What is clear, however, is that that Cornwallis acted during a period of intense agitation in Britain (1788-1792) to abolish the British slave trade which raises the question of whether his actions were a response to metropolitan pressure or an attempt to influence the outcome of the growing debate at home about abolishing the British slave trade, or a combination of the two.

Similar questions are raised by what we know about Charles Grant, a company employee who arrived in India in 1773 and worked closely with Cornwallis before returning to England in 1790 (Aspinall 1987: 11). Back in England, Grant, an evangelical Christian, joined the London Abolition Committee (1791) and was deeply involved in the almost successful attempt in Parliament early in 1793 to ban the British slave trade (Jennings 1997: 67, 81-82). Elected to the Court of Directors in 1794, he served as a director until 1813 and as the company's chairman or deputy chairman six times between 1804 and 1815. Grant has been described as a very influential director

\footnotetext{
${ }^{27}$ PP 1828 XXIV [125], p. 13, Extract of a Letter from Lord Cornwallis, Governor General of India, to the Court of Directors; dated 2 August 1789.

${ }^{28}$ PP 1828 XXIV [125], p. 13, notation at the end of "Extract of a Letter from Lord Cornwallis, Governor General of India, to the Court of Directors; dated 2 August 1789.”

${ }^{29}$ PRO 30/11/210, Narrative of Marquis Cornwallis’s proceedings in India, and an explanation of his plans just prior to his death. Sent to Charles Grant, Chairman of the Court of Directors of the East India Company [Sept. 1805].
} 
(Bowen 2006: 130-32), a characterization which suggests that the court's formal approval in 1796 of the measures taken to suppress slave trading in Malabar ${ }^{30}$ may have reflected abolitionist sentiments at the highest levels of the company's management. The argument by Grant's fellow director, David Scott, that same year about the need to free Bengali salt workers from compulsory labour because 'slaves cannot work so cheap as free men, [and] besides we ought to give all our subjects liberty' (cited in Wright 1960: 184) does likewise. The extent to which abolitionist sentiments continued to shape company policies or influence its employees are raised by various developments during the early nineteenth century, including Governor Frederic North’s decision in 1800 to prohibit slave imports into and exports from Ceylon; ${ }^{31}$ an 1805 proposal to abolish slavery at Penang; ${ }^{32}$ the 1811 ban on the importation and sale of foreign slaves in the Bengal Presidency’s territories; ${ }^{33}$ and Sir Stamford Raffles's call in 1813 for the immediate emancipation of government slaves in Java (captured recently from the Dutch) on the grounds that their labour 'may be superseded by granting a more liberal allowance to ordinary coolies. ${ }^{34}$

Events in the Mascarenes further underscore the need to consider the extent to which developments in the Indian Ocean influenced abolitionist agenda and activities in Britain, the formulation and implementation of imperial policies to suppress slave trading and abolish slavery, and the subsequent recourse to indentured labour. The islands became the centre of a notorious clandestine trade in slaves following their capture by a British expeditionary force in 1810 (Daget 1979; Wanquet 1988; Barker 1996; Allen 2001a). Perhaps 123,400-145,000 men, women, and children were exported from Madagascar, Mozambique, the Swahili Coast, and the Indonesian archipelago to Mauritius and Réunion between 1811 and 1848, mostly before circa 1831 (Allen 2004: 41). The regional importance of the illegal trade to the Mascarenes is suggested by the fact that it may have consumed from one-third to 42.6 percent of an estimated 340,100 to 371,800 trans-oceanic slave exports from eastern Africa during the first half of the nineteenth century (Allen 2010: 68).

\footnotetext{
${ }^{30}$ IOR: E/4/1011, pp. 411-12, Answer to the Letter in the Political Department dated 25 Sept. 1794.

${ }^{31}$ CO 54/2, f. 95r, Frederic North to Court of Directors, 30 Aug. 1800.

${ }^{32}$ IOR: F/4/279/6417, p. 11, Extract General Letter to Prince of Wales Island Dated 18 Feb. 1807.

${ }^{33}$ IOR: F/4/403/10115, pp. 1-2, A.D. 1811. Regulation X.

${ }^{34}$ IOR: G/21/64, [section headed 'Slavery'], Notes of the Arrangements made by Lord Minto for the Occupation and Administration of the Affairs of Java; and of the principal Subjects treated of in the Despatches from the Lieu ${ }^{t}$ Governor of that Island [written by B.J. Jones, 7 Oct. 1813].
} 
This trade's magnitude and the depth of the British commitment to suppressing it made the southwestern Indian Ocean a theatre of operations for anti-slave trade patrols by the Royal Navy well before the British government established an independent naval squadron in November 1819 to conduct such patrols off the West African coast (Klein 2010: 193). The Royal Navy’s activities in the southwestern Indian Ocean during the 1810s and early 1820s were an important, and often overlooked, precursor to the much better known British attempts later in the nineteenth century to end slave exports from East Africa (Howell 1987). The extent of this activity is indicated by the number of captured slave ships and 'prize Negroes’ or 'liberated Africans' condemned by ViceAdmiralty and colonial courts. The Vice-Admiralty court at the Cape of Good Hope condemned twenty-seven slave ships captured by navy cruisers between December 1808 and December 1816 and funnelled more than 2,100 Malagasy and Mozambican prize Negroes into the Cape Colony’s work force as 'apprentices.' Additional seizures during the 1840s swelled the ranks of the Cape's prize Negro population by more than 3,000 (Saunders 1985, 1994). Colonial and Vice-Admiralty courts in Mauritius were even busier, condemning forty-eight captured slave ships between 1811 and 1825, thirty-nine of which were seized between 1815 and $1819 .{ }^{35}$ The number of adjudications handled by Mauritian-based courts during this fourteen-year period exceeded those dealt with by the mixed or joint anti-slave trade commissions at Rio de Janeiro (forty-four) and Surinam (one) between 1819 and 1845, and almost equalled the number of cases (fifty) handled at Havana (Bethell 1966: 84). ${ }^{36}$ As at the Cape, the overwhelming majority of the 4,526 liberated Africans landed on Mauritius were 'apprenticed' to local estate owners for fourteen years. ${ }^{37}$ The Commission of Eastern Enquiry subsequently estimated the value of the labour services provided by these apprentices who were still alive late in 1827 to be at least 100,000 piastres a year. $^{38}$

This commitment to suppressing the illegal trade to Mauritius and the Seychelles also led to increasing British involvement with regional polities, the impact of which resonated for years. In April 1816, Mauritian governor Robert Farquhar initiated

\footnotetext{
${ }^{35}$ CO 167/141, Return No. 19 - Return of the Number of Prize Negroes Apprenticed in the Colony of Mauritius from the Year 1813 to 1827 inclusive.

${ }^{36}$ The mixed commission based in Sierra Leone dealt with 528 such cases during the same period.

${ }^{37}$ On liberated Africans in Mauritius, see Carter, Govinden \& Peerthum 2003.

${ }^{38}$ CO 167/143, p. 8, Report of the Commissioners of Enquiry at Mauritius upon the State of the Prize Negroes Apprenticed in that Colony [27 Jan. 1829]. A sum equal to $£ 20,000$ at the official exchange rate of $£ 1=\$ 5$ in 1826 .
} 
negotiations with the Merina king, Radama I, to end slave exports from those areas of Madagascar under Merina control. Radama was induced to sign such a treaty in October 1817 and again in October 1820 after the first treaty had been abrogated unilaterally by the acting Mauritian governor, Major-General Gage Hall, in 1818. One immediate result of the 1820 accord was to deprive Radama of substantial revenue he had previously enjoyed from taxing slave exports (Scarr 1998: 132). Loss of this revenue and the ultimate failure of his alliance with the British would lead Radama to adopt autarkic policies which resulted in radical changes in the local system of corvée labour, changes that had dire consequences for the Merina economy and imperial regime later in the century (Campbell 2005a: esp. chap. 5).

Because it forced slave traders who had supplied the Mascarenes to shift the centre of their operations from Madagascar to the East African coast, ${ }^{39}$ the 1820 Anglo-Merina accord set the stage for greater British involvement along that coast. In April 1821, Farquhar signalled his intention to secure a treaty with the sultan of Oman, nominal ruler of Zanzibar and other parts of the Swahili Coast, similar to that with Radama. ${ }^{40}$ The following year, Captain Fairfax Moresby, acting on the governor's instructions, negotiated a treaty with Sultan Seyyid Said in which the Omani ruler banned the external traffic in slaves from his East African dominions and prohibited the sale of slaves to any Christian (Gray 1957: 24-29; Beachey 1996: 17-22). Like the 1820 treaty with Radama, the Moresby Treaty had a significant impact on the sultan’s finances, depriving him of perhaps as much as $\$ 56,000$ in revenue each year. ${ }^{41}$ These losses spurred Seyyid’s interest in developing the clove industry on Zanzibar and Pemba (Sheriff 1987: 50), an industry that soon consumed thousands of East African slaves each year. The traffic in chattel labour to these islands would become the focal point of an escalating conflict between Britain and the sultan and his heirs that culminated in the establishment of a British protectorate over Zanzibar in 1873.

Events in Mauritius following the demise of the illegal slave trade circa 1827 likewise had a significant impact not only locally and regionally, but also far beyond the Indian

\footnotetext{
${ }^{39}$ CO 167/57, Despatch No. 46, R.T. Farquhar to Earl Bathurst, 11 June 1821.

${ }^{40}$ PP 1825 XXV [244], p. 37, R.T. Farquhar to Earl Bathurst, 14 April 1821.

${ }^{41}$ Estimates of these losses vary. According to Beachey (1996: 22), the sultan lost $£ 11,250(\$ 56,250)$ a year. Scarr (1998: 132) puts this figure at no more than \$30,000 a year. Abdul Sheriff reports that the sultan claimed losing 40,000-50,000 Maria Theresa dollars (MT\$) each year, or $£ 8,421-£ 10,526$ at the exchange rate of $£ 1=$ MT\$4.75 that prevailed during the first half of the nineteenth century (1987: 50).
} 
Ocean. The increasing inability of Mauritian planters during the 1820s to obtain the labour needed by the island's rapidly expanding sugar industry, coupled with local resentment over slave amelioration policies that had been introduced during the late 1820s, erupted into armed insurrection in 1832 when John Jeremie, a known abolitionist, was appointed as the colony's attorney-general. Although often dismissed as little more than a tempest in a small colonial tea cup, this rebellion exposed the false premises and defective administrative structures upon which the imperial policy of slave amelioration rested, thereby hastening the abolition of slavery throughout the British Empire (Burroughs 1976).

The developments outlined above highlight the need for studies of abolitionism and the overthrow of slavery to transcend the Atlantic-centrism that is a hallmark of important works on these topics (Davis 1966, 1975; Eltis 1987; Blackburn 1988; Drescher 2009) and recent scholarship that situates the origins of abolitionism in a broader British imperial context (Brown 2006). The need to do so is underscored by a small but growing corpus of work on abolition and its aftermath in the Indian Ocean world (Campbell 2005b), and by a growing awareness among some historians of the conceptual and other problems that can result from a reliance on inflexible geographically-defined units of historical analysis. ${ }^{42}$ Some historians of empire also demonstrate a growing appreciation that if there were significant differences between the British experience in the Atlantic and Indian Ocean worlds, there were also important similarities between these two components of a single imperial entity (Marshall 2003). Work on the impact that public knowledge about and perceptions of empire had on British politics and identity (Oldfield 1995; Osborn 2002; Nechtman 2010), the politics and ideology of the early British East India Company state (Stern 2007), and the geography of colour lines in colonial Madras and New York (Nightingale 2008) demonstrate the value of approaching European activities in these two 'worlds' from a pan-oceanic perspective.

However, to argue the need to study the origins, dynamics, and impact of abolitionism within a truly comprehensive imperial context is one thing, to actually do so is

\footnotetext{
${ }^{42}$ See the 2006 forum on conceptualizing the Atlantic world in the William and Mary Quarterly, $3^{\text {rd }}$ ser., vol. 63, no. 4, especially the contributions by Alison Games, Philip J. Stern \& Peter A. Coclanis. For a review of how the Atlantic world has been defined, see Games 2006.
} 
something else. Thirty years ago Hubert Gerbeau discussed the conceptual and other problems inherent in any attempt to reconstruct the history of slavery and slave trading in the Indian Ocean, not the least of which is the dearth of archival materials compared to those that exist for the Atlantic (Gerbeau 1979b). Attempts to reconstruct abolitionist activity in the Indian Ocean and understand how and to what extent developments in the Mare Indicum actively shaped abolitionist discourse and policies face the same problem. The British East India Company archives contain only scattered and often oblique references to the company's involvement in slave trading during the seventeenth and eighteenth centuries (Geber 1998: 101), a fact that helps to explain why histories of the company make little or no mention of its trafficking in and reliance on chattel labour in many of its Indian Ocean establishments (Chaudhuri 1978; Keay 1991; Sen 1998; Bowen 2006). Studies of Portuguese activity in India (Subrahmanyam 1990), the Dutch and French East India companies (Boxer 1965; Haudrère 1989; Winius \& Vink 1994; Subramanian 1999; Wellington 2006), and Indo-European trade and commerce (Das Gupta 1967; Arasaratnam 1986; Das Gupta \& Pearson 1987; Prakash 1998; Sinha 2002) do likewise.

Under such circumstances, coming to grips more fully with the dialogue between the forces of abolitionism in the Indian Ocean and those in the Atlantic during the late eighteenth and early nineteenth century will require adopting research strategies that allow us to explore the complex and often nuanced web of socio-political relationships that linked colonial officials with their counterparts not only in London, but also elsewhere in the imperial world. Recent work on imperial careering during the nineteenth century provides a template for doing so (Lambert \& Lester 2006). Indeed, the applicability of such an approach to abolitionism and its impact in the Indian Ocean is suggested by the career of Robert Farquhar. In 1805, the future governor of Mauritius, acting in his capacity as lieutenant governor of Prince of Wales Island, would recommend the abolition of slavery at Penang on the grounds that this institution was 'the greatest of all evils, \& the attempt to regulate such an evil is in itself almost absurd. $^{43}$

\footnotetext{
${ }^{43}$ IOR: G/34/9, f. 64v, Appendix No. 13, Report of the Lieutenant Governor of Prince of Wales Island, enc. in R.T. Farquhar, Late Lieu ${ }^{t}$ Governor of Prince of Wales Island, to John Lumsden, Chief Secretary to Government, Fort William, 30 Sept. 1805.
} 


\author{
Abbreviations \\ CO - Colonial Office records, National Archives, Kew, United Kingdom; \\ IOR - India Office Records, British Library, London; \\ MGI - Mahatma Gandhi Institute, Moka, Mauritius; \\ PP - British Parliament Sessional Papers; \\ PRO - Domestic records of the Public Record Office, gifts, deposits, notes and transcripts, National \\ Archives, Kew, United Kingdom.
}

\title{
Reference List
}

Adamson, A.H. 1972, Sugar Without Slaves: The Political Economy of British Guiana, 1838-1904. Yale University Press, New Haven.

Allen, R.B. 1999, Slaves, Freedmen, and Indentured Laborers in Colonial Mauritius. Cambridge University Press. Cambridge. 2001a, 'Licentious and Unbridled Proceedings: The Illegal Slave Trade to Mauritius and the Seychelles during the Early Nineteenth Century,' Journal of African History, vol. 42, no. 1: 91116. 2001b, 'Indentured Labor and the Need for Historical Context,' The Historian, vol. 63, no. 2: 39094. 2002, 'Maroonage and Its Legacy in Mauritius and in the Colonial Plantation World,' Outre-mers, Revue d'histoire, vol. 89, no. 2: 131-52.

2004, 'The Mascarene Slave-Trade and Labour Migration in the Indian Ocean during the Eighteenth and Nineteenth Centuries,' in The Structure of Slavery in Indian Ocean Africa and Asia (ed.) Gwyn Campbell, Routledge, London, 33-50.

2005, 'Carrying Away the Unfortunate: The Exportation of Slaves from India during the Late Eighteenth Century,' in Le monde créole: Peuplement, sociétés et condition humaine, $X V I I^{e}-X X^{e}$ siècles (ed.) J. Weber, Les Indes Savantes, Paris, 285-98.

2006, 'A Traffic Repugnant to Humanity: Children, the Mascarene Slave Trade and British Abolitionism,' Slavery and Abolition, vol. 27, no. 2: 219-36.

2008, 'The Constant Demand of the French: The Mascarene Slave Trade and the Worlds of the Indian Ocean and Atlantic during the Eighteenth and Nineteenth Centuries,' Journal of African History, vol. 49, no. 1: 43-72.

2009, 'Suppressing a Nefarious Traffic: Britain and the Abolition of Slave Trading in India and the Western Indian Ocean, 1770-1830,' William and Mary Quarterly, 3rd ser., vol. 66, no. 4: 873-94. 2010, 'Satisfying the "Want for Labouring People": European Slave Trading in the Indian Ocean, 1500-1800,' Journal of World History, vol. 21, no. 1: 45-73.

Anderson, C. 2000, Convicts in the Indian Ocean: Transportation from South Asia to Mauritius, 181553. Macmillan Press, London.

2007, 'Sepoys, Servants and Settlers: Convict Transportation in the Indian Ocean, 17871945,' in Cultures of Confinement: A History of the Prison in Africa, Asia and Latin America (eds) Frank Dikötter \& Ian Brown, Cornell University Press, Ithaca, NY, 185-220.

Arasaratnam, S. 1986, Merchants, Companies and Commerce on the Coromandel Coast, 1650-1740. Oxford University Press, Delhi.

Armstrong, J.C. 1999, 'The Ceylon Connection: Convicts and Exiles from Ceylon Sent to the Cape of Good Hope during the Dutch East India Company Period,' paper presented to the interdisciplinary conference on "Colonial Places, Convict Spaces: Penal Transportation in Global Context, c. 16001940,”' University of Leicester, 9-10 Dec.

Aspinall, A. 1987, Cornwallis in Bengal. Uppal Publishing House, New Delhi.

Baak, P.E. 1999, 'About Enslaved Ex-slaves, Uncaptured Contract Coolies and Unfreed Freedmen: Some Notes about "Free" and "Unfree" Labour in the Context of Plantation Development in Southwest India, Early Sixteenth Century-Mid 1990s,’ Modern Asian Studies, vol. 33, no. 1: 121-57.

Barker, A.J. 1996, Slavery and Antislavery in Mauritius, 1810-33: The Conflict between Economic Expansion and Humanitarian Reform under British Rule. Macmillan, London.

Beachey, R.W. 1996, A History of East Africa, 1592-1902. I.B. Tauris, London.

Behal, R.P., \& Mohapatra, P.P. 1992, 'Tea and Money Versus Human Life: The Rise and Fall of the Indenture System in the Assam Tea Plantations, 1840-1908,' Journal of Peasant Studies, vol. 19, nos. 3-4: 142-72.

Bethell, L. 1966, 'The Mixed Commissions for the Suppression of the Transatlantic Slave Trade in the Nineteenth Century,' Journal of African History, vol. 7, no. 1: 71-93. 
Blackburn, R. 1988, The Overthrow of Colonial Slavery, 1776-1848. Verso, London.

Bowen, H.V. 2006, The Business of Empire: The East India Company and Imperial Britain. Cambridge University Press, Cambridge.

Boxer, C.R. 1965, The Dutch Seaborne Empire, 1600-1800. Knopf, New York.

Breman, J. 1989, Taming the Coolie Beast: Plantation Society and the Colonial Order in Southeast Asia. Oxford University Press, Delhi.

Brereton, B. 1994, 'The Other Crossing: Asian Migrants in the Caribbean. A Review Essay,' Journal of Caribbean History, vol. 28, no. 1, 99-122.

Brown, C.L. 2006, Moral Capital: Foundations of British Abolitionism. University of North Carolina Press, Chapel Hill.

Burroughs, P. 1976, 'The Mauritius Rebellion of 1832 and the Abolition of British Colonial Slavery,' Journal of Imperial and Commonwealth History, vol. 4, no. 3, 243-65.

Campbell, G. 2005a, An Economic History of Imperial Madagascar, 1750-1895. Cambridge University Press, Cambridge. (ed.) 2005b, Abolition and Its Aftermath in Indian Ocean Africa and Asia. Routledge, London.

Carter, M. 1994, Lakshmi's Legacy: The Testimonies of Indian Women in $19^{\text {th }}$ Century Mauritius. Éditions de l’Océan Indien, Rose Hill, Mauritius. 1995, Servants, Sirdars and Settlers: Indians in Mauritius, 1834-1874. Oxford University Press, Delhi.

Carter, M. \& Gerbeau, H. 1988, 'Covert Slaves and Coveted Coolies in the Early $19^{\text {th }}$ Century Mascareignes,' Slavery and Abolition, vol. 9, no. 3: 194-208.

Carter, M., Govinden, V. \& Peerthum, S. 2003, The Last Slaves: Liberated Africans in $19^{\text {th }}$ Century Mauritius. Centre for Research on Indian Ocean Societies, Port Louis.

Carter, M. \& Ng, J. 1997, Forging the Rainbow: Labour Immigrants in British Mauritius. Alfran Company Ltd., Mauritius.

Chattopadhyay, A.K. 1977, Slavery in the Bengal Presidency, 1772-1843. Golden Eagle Publishing House, London.

Chaudhuri, K.N. 1978, The Trading World of Asia and the English East India Company, 1660-1760. Cambridge University Press, Cambridge.

Cumpston, I.M. 1953, Indians Overseas in British Territories, 1834-1854. Oxford University Press, London.

Daget, S. 1979, 'British Repression of the Illegal French Slave Trade: Some Considerations,' in The Uncommon Market: Essays in the Economic History of the Atlantic Slave Trade, (eds) H.A. Gemery \& J.S. Hogendorn, Academic Press, New York, 419-42. 1996, 'Révolution ajournée: Bourbon et la traite illégale française, 1815-1832,' in Révolution française et Océan Indien: Prémices, paroxysmes, héritages et deviances, (eds) C. Wanquet \& B. Jullien, L’Harmattan, Paris, 333-46.

Das Gupta, A. 1967, Malabar in Asian Trade, 1740-1800. Cambridge University Press, Cambridge.

Das Gupta, A. \& Pearson, M. N. (eds) 1987, India and the Indian Ocean, 1500-1800. Oxford University Press, Calcutta.

Das Gupta, R. 1992, 'Plantation Labour in Colonial India,' in Plantations, Proletarians and Peasants in Colonial Asia (eds) E. V. Daniel, H. Bernstein \& T. Brass, Frank Cass, London, 173-98.

Dasgupta, K.a 2005, 'Plantation Labour in the Brahmaputra Valley: Regional Enclaves in a Colonial Context,' in Abolition and Its Aftermath in Indian Ocean Africa and Asia, (ed.) Gwyn Campbell, Frank Cass, London, 169-79.

Davis, D.B. 1966, The Problem of Slavery in Western Culture. Cornell University Press, Ithaca, NY. 1975, The Problem of Slavery in the Age of Revolution, 1770-1823. Cornell University Press, Ithaca, NY.

Drescher, S. 2009, Abolition: A History of Slavery and Antislavery. Cambridge University Press, New York.

Duncan, J., Page, W., Boddam, C. \& Dow, A. 179?, Reports of a Joint Commission from Bengal and Bombay, Appointed to Inspect into the State and Condition of the Province of Malabar in the Years 1792 and 1793, 3 vols., Bombay.

Eltis, D. 1987, Economic Growth and the Ending of the Transatlantic Slave Trade. Oxford University Press, Oxford.

Eltis, D. \& Richardson, David 2008, ‘A New Assessment of the Transatlantic Slave Trade,' in Extending the Frontiers: Essays on the New Transatlantic Slave Trade Database, (eds) D. Eltis \& D.

Richardson, Yale University Press, New Haven, 1-60. 
Finch, H. 2005, ‘Comprendre la traite illégale d'esclaves pendant l’occupation britannique de La Réunion à travers les archives britanniques,' in Identité et société réunionnaise: Nouvelles perspectives et nouvelles approaches, (eds) L. Médéa, L. Labache \& F. Vergès. Karthala, Paris, 67-88.

Forster, C. 2002, 'Convicts: Unwilling Migrants from Britain and France,' in Coerced and Free Migration: Global Perspectives, (ed.) David Eltis, Stanford University Press, Stanford, 259-91.

Fuma, S. 2000, 'La traite des esclaves dans le bassin du sud-ouest de l'Océan Indien et la France après 1848,' in La route des esclaves: Système servile et traite dans l'est malgache, (ed.) Ignace Rakoto, L'Harmattan, Paris, 247-61.

Games, A. 2006, 'Atlantic History: Definitions, Challenges, and Opportunities,' American Historical Review, vol. 111, no. 3: 741-57.

Geber, J.L. 1998, 'The East India Company and Southern Africa: A Guide to the Archives of the East India Company and the Board of Control, 1600-1858,' unpublished PhD thesis, University College London.

Gerbeau, H. 1979a, ‘Quelques aspects de la traite illégale des esclaves à l’Ile Bourbon au XIX ${ }^{\mathrm{e}}$ siècle,' in Mouvements de populations dans l'Océan Indien, UNESCO, Paris, 273-308. 1979b, 'The Slave Trade in the Indian Ocean: Problems Facing the Historian and Research to be Undertaken,' in The African Slave Trade from the Fifteenth to the Nineteenth Century, U.N.E.S.C.O., Paris, 184-207. 1986, 'Engagees and Coolies in Réunion Island: Slavery’s Masks and Freedom’s Constraints,' in Colonialism and Migration: Indentured Labour Before and After Slavery, (ed.) P.C. Emmer, Martinus Nijhoff, Dordrecht, 209-36. 2002, 'L’Océan Indien n’est pas l'Atlantique: La traite illégale à Bourbon au XIX ${ }^{\mathrm{e}}$ siècle,' Outremers, Revue d'histoire, vol. 89, no. 336-37: 79-108.

Gillion, K.L. 1962, Fiji’s Indian Migrants: A History to the End of Indenture in 1920. Oxford University Press, Melbourne.

Graves, A. 1993, Cane and Labour: The Political Economy of the Queensland Sugar Industry. Edinburgh University Press, Edinburgh.

Gray, Sir J. 1957, The British in Mombasa, 1824-1826. Macmillan, London.

Grubb, F. 2000, 'The Transatlantic Market for British Convict Labor,' Journal of Economic History, vol. 60, no. 1: 94-122.

Haudrère, P. 1989, La Compagnie des indes française au XVIII ${ }^{e}$ siècle (1719-1795). Librairie de l'Inde, Paris.

Hjejle, B. 1967, 'Slavery and Agricultural Bondage in South India in the Nineteenth Century,' Scandinavian Economic History Review, vol. 15, nos. 1-2: 71-126.

Hoefte, R. 1998, In Place of Slavery: A Social History of British Indian and Javanese Laborers in Suriname. University Press of Florida, Gainesville.

Howell, R. 1987, The Royal Navy and the Slave Trade. St. Martin’s Press, New York.

Jain, R.K. 1970, South Indians on the Plantation Frontier in Malaya. Yale University Press, New Haven. 1984, 'South Indian Labour in Malaya, 1840-1920,' in Indentured Labour in the British Empire, 1834-1920,(ed.) K. Saunders, Croom Helm, London, 158-82.

Jennings, J. 1997, The Business of Abolishing the British Slave Trade, 1783-1807. Frank Cass, London.

Jolly, M. 1987, 'The Forgotten Women: A History of Migrant Labour and Gender Relations in Vanuatu,' Oceania, vol. 58, no. 2: 119-39.

Joseph, S. 1987, 'Slave Labour of Malabar in the Colonial Context,' in Essays in Modern Indian Economic History, (ed.) S. Bhattacharya, Munshiram Manoharlal Publishers, New Delhi, 44-54.

Kale, M. 1998, Fragments of Empire: Capital, Slavery, and Indian Indentured Labor in the British Caribbean. University of Pennsylvania Press, Philadelphia.

Keay, J. 1991, The Honourable Company: A History of the English East India Company. HarperCollins, London.

Klein, H.S. 2010, The Atlantic Slave Trade. $2^{\text {nd }}$ ed. Cambridge University Press, Cambridge.

Kumar, D. 1965, Land and Caste in South India: Agricultural Labour in the Madras Presidency during the Nineteenth Century. Cambridge University Press, Cambridge.

Kurup, K.K.N. 1973, 'Slavery in 18 ${ }^{\text {th }}$ Century Malabar,' Revue historique de Pondichéry, vol. 11: 56-60.

Lal, B.V. 1983, Girmitiyas: The Origins of the Fiji Indians. Journal of Pacific History, Canberra.

Lambert, D., \& Lester, A. (eds) 2006, Colonial Lives Across the British Empire: Imperial Careering in the Long Nineteenth Century. Cambridge University Press, Cambridge.

Laurence, K.O. 1994, A Question of Labour: Indentured Immigration into Trinidad and British Guiana, 1875-1917. St. Martin's Press, New York.

Look Lai, W. 1993, Indentured Labor, Caribbean Sugar: Chinese and Indian Migrants to the British West Indies, 1838-1918. Johns Hopkins University Press, Baltimore. 
Ly-Tio-Fane Pineo, H. 1979, ‘Aperçu d’une immigration forcée: L’importation d’africains libérés aux Mascareignes et aux Seychelles, 1840-1880,' in Minorités et gens de mer en Océan Indien, XIX $X^{e}$ $X X^{e}$ siècles, IHPOM Études et Documents, Aix-en-Provence, No. 12, 73-84. 1984, Lured Away: The Life History of Indian Cane Workers in Mauritius. Mahatma Gandhi Institute Press, Moka, Mauritius.

Mandle, J.R. 1973, The Plantation Economy: Population and Economic Change in Guyana, 1838-1960. Temple University Press, Philadelphia.

Marks, S., \& Richardson, P. 1984, 'Introduction,' in International Labour Migration: Historical Perspectives, (eds) S. Marks \& P. Richardson, M. Temple Smith, Hounslow, 1-18.

Marshall, P.J. 2003, 'The Caribbean and India in the Later Eighteenth Century: Two British Empires or One?' in P.J. Marshall, 'A Free Though Conquering People': Eighteenth-Century Britain and Its Empire, Aldershot, Ashgate, chap. 10.

Mayer, A.C. 1963, Indians in Fiji. Oxford University Press, London.

Mettas, J. 1978, Répertoire des expéditions négrières françaises au XVIII siècle, vol. 1, Nantes, Société Française d'Histoire d'Outre-Mer, Paris.

Mohammed, P. 1995, 'Writing Gender into History: The Negotiation of Gender Relations among Indian Men and Women in Post-Indenture Trinidad Society, 1917-47,' in Engendering History: Caribbean Women in Historical Perspective, (eds) V.A. Shepherd, B. Brereton \& B. Bailey, James Currey, London, 20-47.

Monnier, J.-E. 2006, Esclaves de la canne à sucre: Engagés et planteurs à Nossi-Bé, Madagascar, 18501880. L'Harmattan, Paris.

Munro, D. 1993, 'The Pacific Islands Labour Trade: Approaches, Methodologies, Debates,' Slavery and Abolition, vol. 14, no. 2: 87-108. 1995, 'The Labor Trade in Melanesians to Queensland: An Historiographic Essay,' Journal of Social History, vol. 28, no. 3: 609-27.

Nechtman, T.W. 2010, Nabobs: Empire and Identity in Eighteenth-Century Britain. Cambridge University Press, Cambridge.

Newbury, C. 1975, 'Labour Migration in the Imperial Phase: An Essay in Interpretation,' Journal of Imperial and Commonwealth History, vol. 3, no. 2: 234-56.

Nightingale, C.H. 2008, 'Before Race Mattered: Geographies of the Color Line in Early Colonial Madras and New York,' American Historical Review, vo1. 13, no. 1: 48-71.

Northrup, D. 1995, Indentured Labor in the Age of Imperialism, 1834-1922. Cambridge University Press, Cambridge.

Osborn, J. 2002, 'India and the East India Company in the Public Sphere of Eighteenth-Century Britain,' in The Worlds of the East India Company, (eds) H.V. Bowen, M. Lincoln \& N. Rigby, Boydell Press, Woodbridge, 201-21.

Oldfield, J.R. 1995, Popular Politics and British Anti-Slavery: The Mobilisation of Public Opinion against the Slave Trade. Manchester University Press, London.

Prakash, O. 1998, European Commercial Enterprise in Pre-colonial India. Cambridge University Press, Cambridge.

Ramasamy, P. 1992, 'Labour Control and Labour Resistance in the Plantations of Colonial Malaya,' Journal of Peasant Studies, vol. 19, nos. 3-4, 87-105.

Rediker, M., Pybus, C. \& Christopher, E. 2007, 'Introduction,’ in Many Middle Passages: Forced Migration and the Making of the Modern World, (eds) E. Christopher, C. Pybus \& M. Rediker, University of California Press, Berkeley, 1-19.

Renault, F. 1976, Libération d'esclaves et nouvelle servitude: Les rachats de captives africains pour le compte des colonies françaises après l'abolition de l'esclavage. Les Nouvelles Éditions Africaines, Paris.

Richardson, P. 1984, 'Coolies, Peasants, and Proletarians: The Origins of Chinese Indentured Labour in South Africa, 1904-1907,’ in International Labour Migration: Historical Perspectives (eds) Shula Marks \& Peter Richardson, M. Temple Smith, Hounslow, 167-85.

Ross, C. (ed.) 1859, Correspondence of Charles, First Marquis Cornwallis. $2^{\text {nd }}$ ed., 3 vols. J. Murray, London.

Saunders, C.r 1985, 'Liberated Africans in Cape Colony in the First Half of the Nineteenth Century,' International Journal of African Historical Studies, vol. 18, no. 2: 223-39. 1994, “"Free, Yet Slaves”: Prize Negroes at the Cape Revisited,' in Breaking the Chains: Slavery and Its Legacy in the Nineteenth-Century Cape Colony, (eds) Nigel Worden \& Clifton Crais, Witwatersrand University Press, Johannesburg, 99-115.

Scarr, D, 1998, Slaving and Slavery in the Indian Ocean, Macmillan, London. 
Schuler, M. 1980, Alas, Alas, Kongo: A Social History of Indentured African Immigration into Jamaica, 1841-1865, Johns Hopkins University Press, Baltimore.

Sen, S. 2000, Disciplining Punishment: Colonialism and Convict Society in the Andaman Islands, Oxford University Press, New Delhi.

Sen, S. 1998, Empire of Free Trade: The East India Company and the Making of the Colonial Marketplace, University of Pennsylvania Press, Philadelphia.

Shepherd, V.A. 1995, 'Gender, Migration and Settlement: The Indentureship and Post-Indentureship Experience of Indian Females in Jamaica, 1845-1943,' in Engendering History: Caribbean Women in Historical Perspective, (eds) V.A. Shepherd, B. Brereton \& B. Bailey, James Currey, London, 233-57. 2002 'The “Other Middle Passage?” Nineteenth-Century Bonded Labour Migration and the Legacy of the Slavery Debate in the British-Colonized Caribbean,' in Working Slavery, Pricing Freedom: Perspectives from the Caribbean, Africa and the African Diaspora, (ed.) V.A. Shepherd, Palgrave, New York, 343-75.

Sheriff, A. 1987, Slaves, Spices and Ivory in Zanzibar, James Currey London.

Shineberg, D. 1999, The People Trade: Pacific Island Laborers and New Caledonia, 1865-1930. University of Hawai'i Press, Honolulu.

Shlomowitz, R. 1982, 'Melanesian Labor and the Development of the Queensland Sugar Industry,' Research in Economic History, vol. 7: 327-61.

Sinha, A. 2002, The Politics of Trade: Anglo-French Commerce on the Coromandel Coast, 1763-1793. Manohar, New Delhi.

Stern, P. J. 2007, 'Politics and Ideology in the Early East India Company-State: The Case of St. Helena, 1673-1709,' Journal of Imperial and Commonwealth History, vol. 35, no. 1: 1-23.

Subramanian, L. (ed.) 1999, The French East India Company and the Trade of the Indian Ocean: A Collection of Essays by Indrani Ray. Munshiram Manoharlal Publishers, New Delhi.

Subrahmanyam, S. 1990, Improvising Empire: Portuguese Trade and Settlement in the Bay of Bengal, 1500-1700. Oxford University Press, Delhi.

Tayal, M. 1977, 'Indian Indentured Labor in Natal, 1890-1911,' Indian Economic and Social History Review, vol. 14, no. 4: 519-47.

Tinker, H. 1974, A New System of Slavery: The Export of Indian Labour Overseas, 1830-1920. Oxford University Press, London.

Trans-Atlantic Slave Trade Database 2009, Emery University. Voyages. Online, available: http://slavevoyages.org/tast/database/search.faces (Accessed January 12012 ).

Udaya, B. 2003, 'Slavery on the Kanara Coast in the Early $19^{\text {th }}$ Century,' Indica, vol. 40, no. 1: 13-28.

Van Den Boogaart, E., \& Emmer, P. C. 1986, 'Colonialism and Migration: An Overview,' in Colonialism and Migration: Indentured Labour Before and After Slavery, (ed.) P.C. Emmer, Martinus Nijhoff, Dordrecht, 3-15.

Wanquet, C. 1988, 'La traite illégale à Maurice à l'époque anglaise (1811-1835),' in De la traite à l'esclavage: Actes du colloque internationale sur la traite des noirs, Nantes, 1985, (ed.) Serge Daget, vol. 2, Centre de Recherche sur l'Histoire du Monde Atlantique, Nantes, 451-66.

Ward, K. 2009, Networks of Empire: Forced Migration in the Dutch East India Company. Cambridge University Press, Cambridge.

Weber, J. 2002, 'L’émigration indienne à La Réunion: “Contraire à la morale” ou "utile à l'humanité”? (1829-1860),' in Esclavage et abolitions dans l'Océan Indien, 1723-1860, (ed.) Edmond Maestri, L’Harmattan, Paris, 309-28.

Wellington, D.C. 2006, French East India Companies: A Historical Account and Record of Trade. University Press of America, Lanham, MD.

Winius, G.D., \& Vink, M.P.M. 1994, The Merchant-Warrior Pacified: The VOC (the Dutch East India Company) and Its Changing Political Economy in India. Oxford University Press, Delhi.

Wright, H.R.C. 1960, 'Raffles and the Slave Trade at Batavia in 1812,' The Historical Journal vol. 3, no. 2: $184-91$.

Yang, A.A. 2003, 'Indian Convict Workers in Southeast Asia in the Late Eighteenth and Early Nineteenth Centuries,' Journal of World History, vol. 14, no. 2: 179-208. 